\title{
広域利水における水配分計画モデルに関する一考察 \\ STUDY ON A MATHEMATICAL MODEL FOR WATER DISTRIBUTION PLANNING IN THE LARGESCALE WATER RESOURCE DEVELOPMENT
}

\section{1. 緒言}

近年, 人口の増大とその都市への集中, 経済の高度成 長, 生活水準の高度化と様式の多様化, その他諸々の経 済的・社会的変化を反映して水需要が急激に増大し, 将 来における媣刻な水不足が䀣念されている。特にこの傾 向の著しい首都圏・阪神都市圈などでは, 従来の一水系 開発主義による解決が不可能になりつつある。建設省の 昭和 60 年における水需要の予測によれば, 京浜・京葉 地域では, 年間 31 億トンという膨大な水不足が, また 京阪神地域においては, 年間 19 億トンの水不足が生ず るものと算定されている。これら両地域では, それぞれ 利根川・淀川という大水系によって水が供給されている が，その水需要はきわめてひっ迫していることになる。 このため, 利根川には新規にダムなどの施設を 28 か所 建設し，布川地点で利用率をほぼ限界の約 $62 \%$ と設定 している。また淀川でも23 か所にダムなどの施設を建 設して，枚方地点で利用率を開発限度の約 $59 \%$ にまで 高めることにしているが，これでもなお水需要を充足す ることはできない状況にある。このように水不足の予想 される地方が存在するのに対して, 一方では, なお大き な供給力が残されていると考えられる地域が 28 地域も 存在している。

このように地域によって水需給のバランスの程度が異 なっているので, 水資源の有効利用という点からは, 従 来の常識的な需給圈を越えた水の融通方法を考えていく ことが重要課題となってくる。このためには複数の水系 を含む広域的な地域を対象としたダム群と他の利水施設 の計画を水源開発の方式にとり入れていくことが最も有 効な手段の一つになってくると思われる。この場合, 各 地域ごとに個別にダムを建設したり, 導水路を建設した りしていると効率的な水源開発とその利用を促進するこ

\footnotetext{
* 正会員 工博 京都大学助教授 工学部土木工学科

** 正会員 工修 京都大学助手 工学部土木工学科
}

\author{
春名 攻*・岡 田 憲 夫** \\ By Mamoru Haruna and Norio Okada
}

とができない。したがって各行政体は従来のように単独 で利水計画を策定するのではなくて，相互の間の調整を はかって総合的な計画を作り上げることが要請されてく る。さらに国の立場からみても, 個々では不可能な計画 の統一・調整の必要性がでてくる。このように利水計画 が広域利水の方向に進む以上, 計画間の総合的な調整方 法と合理化の提案が必要になってくると考えてょかろ う。もちろんこのような広域利水計画を実施するために は, 行政的な問題や住民感情などの点でいろいろ困難な 点が多く, 今後このような観点からの分析や検討も必要 であろら。

一方, 水需給の問題の解決のための方法には，このよ うな広域利水とは別の方向からのアプローチも考えられ よう。すなわち節水や水利用体系の変換をも含めた水の 効率的な使用の促進といらアプローチである。この方法 は広域利水が主として水の量に注目していたのに対し て，その使用に際して不必要な口スをなくするととも に，全く別の角度から水を生み出すことにより実質的に 供給可能水量を増加させようとするものである。その方 法の主なものをあげれば次のようになる。

(1) 用途別給水システムと下水還元水の再利用

(2) 海水の淡水化

(3) 農業用水等既得水利権の一部の都市用水一の転換

(4) 水使用における節水

(5) 水道施設の漏水の防止

これらの方法は, 技術的・経済的な問題に未解決な点 が多く, 一部の地域や特殊なケースを除いて実現性の乏 しいのが実情である。またかりにこれらの方法が技術的 ・経済的に叫能であっても, その実現には水使用形態の 変更や, 水利用における価値観の転換がかなりの程度必 要であり，水使用に際しての協力態勢が要求される。

本研究においては, 今後検討していかね枚ばなない諸 々の水需給問題の解決法のうちでも, 最も実現性の高い と考えられる広域利水の問題をとりあげ，特にそのうち 
でも, ダムなどの水源開発と導水路・配水網の建設計画 を対象とした合理的な水配分計画のモデル化を試みるこ とにした。

\section{2. 広域利水における水配分計画のモデル化}

\section{（1） モデル化における前提}

広域利水計画の問題は, 本研究でとりあげる施設建設 計画の側面以外に, 行政的・経済的な諸々の側面からの 考察が必要である。また問題を単に利水の問題としてと らえるだけでは不十分で，人工導水路を建設し，ダムに 大量の水を貯留することにより引き起こされる諸々の水 理現象にいかに対処するかを考えることも重要である。 しかし，ここでは考察の対象を広域利水計画のなかでも とくに重要と考えられる水配分問題に限定し, 合理的な 施設建設計画のための計画モデルを作成する之上もに， 適用例をとおしての実証的分析を行ならことにする。

さて，モデル化にあたっては，まず広域利水システム のもつ構造に注目する (図一1)。すなわち導水路, 配水 網の建設にも, 大きな導水路を作り大需要地とを結ぶも のから, 浄水場と家庭とを結ぶ上水道の配水網といった 種々の段階が存在している。さらに, 各段階においてダ ムなどの水源施設を建設する側面と水源と需要地とを結 ぶための導水路・配水網を建設するといら側面がある。 特に後者は地域的な利害に直接関係することが多いが， これは導水路・配水網の建設の多くが地方公共団体, 各 種水利組合などの直接・間接的な要請に対応して実施さ れるからである。これに対して, ダム建設計画は, 建設 省・農林省などの国レベルにおいて策定されるか, ある いは都道府県などのより上位の地方行政体が担当する場 合が多い。これはダムなどの水源開発計画は, その建設 に要する費用がきわめて膨大であることに加えて，それ が単に地域的な利水計画にとどまらず，広域的な国土開

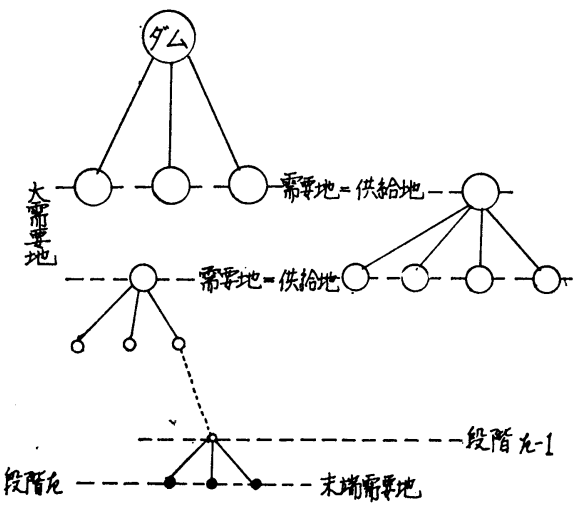

図一1 広域利水における各種のレベル
発計画に強く関係する場合が多いことによる。

このように，両者の立場が異なっている点に注目すれ ば, 広域利水を実現するためには, 各種導・配水網を代 表する種々の利害とダムなどの水源開発を代表する利害 との間を総合的に調整するといら機能が重要になってく る。したがって以下の議論では問題をダム群の建設と導 水路網の建設に限定して, これを総合的にとりあつかっ ていくといら計画問題を取扱からこととする。

\section{（2）モデルの構造}

これまでに示した広域利水の目的にしたがって，以下 に述べる広域利水計画のモデルにおいては，次のような 機能を組み込むことにする。

(1) 建設するダムの位置選定と規模を計画する機能。

(2) 建設されるダムと需要地とを結ぶ導水路網の位置 ・規模を計画する機能。

(3) (1)，(2)の計画を合理的に調整する機能。

このらち，(3の総合調整の機能を実現するにあたって は，なんらかの評価のための基準が必要であるが，ここ では, 広域的な観点からの評価といらことから, ダム群 と導水路網の建設費の総和を最小にするといら評価基準 を採用することにした。したがって，以下においては， ダム群と導水路網で取扱われる水量の間の需給関係の制 約を満たし，かつ最小の総費用を与えるような計画を選 び出す過程を検討することによって，「総合調整のプロ セス」に関する考察を行ならことにする。

\section{（3）定 式 化}

モデルの定式化にあたって，まず以下のような記号を 定義しておく。

$D_{j}:$ 需要地 $j(j=1,2, \cdots, n)$ における需要量

$D:$ 対象地域における需要量の総和 $\left(=\sum_{j=1}^{n} D_{j}\right)$

$A_{i}:$ 建設するダムの候補地 $i(i=1,2, \cdots, m)$ にお ける建設可能規模の最大值

$y_{i}$ : ダム $i$ の建設規模を表わす指標 $\left(0 \leqq y_{i} \leqq 1\right)$ 。 したがって建設されるダムの規模は $y_{i} A_{i}(0 \leqq$ $\left.y_{i} A_{i} \leqq A_{i}\right)$ によって表わされる。

$x_{i j}$ : ダム建設の候補地 $i$ から需要地 $j$ への送水量。 モデルにおける変数としては, 各ダム候補地から需要 地へ送る水の量 $x_{i j}$ と, 各ダムをどの程度に建設するか を示寸指標の值 $y_{i}$ の 2 種の変数があげられるが，これ らの変数が同時に満たすべき制約条件としては，供給少 イド（ダム候補地）と需要サイド（水需要地）の間の水 量のバランス関係がある。一般䎲ダムから各需要地一供 給される供給量の総和は, 各需要地の需要量以上でなけ ればならない。すなわち, 理論的には, 供給量が需要量 以上であれば実行可能な計画が求められる。しかし，実 
際問題としては, 予測された需要量に誤差が生じらるこ とや, 需要量の時期的変動, さらに送水時の漏水を始め とする無効水量などが存在しているので, これらの誤差 を見込まないで供給量を定めると，実行不可能な計画を 作成することになるが，一方では，ここでの目的が厳密 な意味でのダムや導水路網の建設計画ではなくて, むし ろ広域的な水配分問題を作成することにあるので, 要求 されるダムや導水路の建設位置や費用の算定は, 水配分 問題として要求される程度の大まかなものでよいと考え られる。このことは, あらかじめ需要量の算定にあたっ て, 予測值の誤差, 時期的変動, 漏水を始めとする無効 給水量などを見込んだ平均的な值を求めておくことにす れば問題はないであろ5。また以下で示すように，計画 モデルが線形計画として定式化される場合，不等号を等 号とおいてしまっても, 理論的には同一の最適解が得ら れるという保証があるので, 以下のモデルにおいては需 要量と供給量を等しいとおいて論を進めることにする。

以上に基づき, 計画モデルにおける制約条件を以下の ように設定する。

$$
\left.\begin{array}{l}
\left.\begin{array}{l}
\sum_{i=1}^{m} x_{i j}=D_{j} \\
x_{i j} \geqq 0 \quad(i=1,2, \cdots, m ; j=1,2, \cdots, n)
\end{array}\right\} \\
\cdots \cdots \cdots(1) \\
\sum_{i=1}^{m} A_{i} y_{j} \doteq D \\
0 \leqq y_{i} \leqq 1 \quad(i=1,2, \cdots, m)
\end{array}\right\} \cdots \cdots \cdots \cdots \cdot(2)
$$

さて, 式 (1) は導水路網施設の計画 (需要地で必要と する水量を供給地からどのように導水すればよいかを決 定する計画）が実行可能であるための条件を表わしたも のであるが，供給地における供給可能条件を全く考慮し ていない。一方, 式 (2) はダムの計画の代替案を選択す る方式を定式化したものであるが，式（1）を満たすよう な導水路施設の計画の斉合性を考えてはいない。しかも 式 (1)，(2) を満たすよらなダムと導水路網の計画が求 められたとしても, 全体として実行可能な計画が求めら れているかどらかわからないし，建設費の総和が最小と いら立場からみると, 必ずしも最適な計画が求められて いるかどらかわからない。したがって全体で実行可能か つ最適な計画を求めるためには, 式 (1)，(2) によって 求められるダムと導水路網計画の代替案が次の要件を満 たしていなければならない。

目的関数 :

$$
z=\sum_{i=1}^{m} \sum_{j=1}^{n} c_{i j} x_{i j}+\sum_{i=1}^{m} R_{i} y_{i} \rightarrow \min .
$$

制約条件：

$$
\begin{array}{r}
-\sum_{j=1}^{n} x_{i j}+A_{i} y_{i} \geqq 0 \cdots \cdots \cdots \cdots \cdots \cdots \\
\quad(i=1,2, \cdots, m ; j=1,2, \cdots, n)
\end{array}
$$

ここに,

$c_{i j}:$ ダムの建設候補地 $i$ から需要地 $j$ へ敷設する 導水路網の建設単価

$R_{i}$ : ダム建設候補地 $i$ の建設可能規模の 最大值に 対応する建設費

以上の式 (1)，(2)，(3)，(4) からなるモデルが, 広 域利水の計画モデルを表わしているが，これは大型の線 形計画 (以下 LP と呼ぶ) の問題になっている。した がって, 目的が単に最適解を得るだけであるならば, 比 較的容易に LP の一般の解法（シンプレックス法）を用 いて最適解を得ることができる。しかし，式 (1)，(2)の 制約条件の数が膨大になってくると, 後に述べるような ディコンポジションによる簡便な解法によらないで一般 の LP の解法を導入するのは, 計算効率上得策でなくな る。さらに重要なことは, 本研究で意図していること が, 単にそのような計算技術上の問題だけではなく, 広 域利水システムの構造を解明しょうとすることにある点 である。すなわち，2．（2）でも述べたように，本研究 ではダム群と導水路網で取扱われる水量の間に存在する 全体的な需給関係を満たし，かつ最小の総費用を与える ような計画を選び出す過程を含んだモデルを作成し分析 することを主眼としているが，このような計画化のプロ セスが，以下に示すディコンポジションの原理ならびに それに基づく解法のプロセスとよく対応していることを 示そらとするものである。以下においては本計画モデル における LP のディコンポジションの原理と解法の内容 ならびにその役割について述べていくことにする。

\section{3. ディコンポジションモデルの数学的構造}

\section{(1) 数学的構造}

ここではまず式 (1) のみを満たすような解を導水路網 計画の代替案であるとし，また同様に式 (2) のみを満た すような解をダム群の計画代替案であると考えることに する。ここでは, 式 (1)〜 (4) よりなる LP の問題に対 する解を求めることだけを目的とはせず, 式 (1) あるい は式 (2) より選び出された代替案をどのように用いて全 体で実行可能な計画を作成していけばよいかといらこと を検討することにするが，後述するように，最適な全体 計画を作成していくプロセスにおいては，ダム群と導水 路網の計画に対する代替案の組合わせを順次検討してい くといら方法がとられる。そこでは，実行可能な代替案 が多数求めらるが, 最適な計画を効率的に求めていくた めには，それらを有効に利用していくことが必要であ る。このため以下においては, 後の議論にとって必要な 実行可能な代替案とモデル式との関係を明らかにしてい 
くことにする。

式（1），(2）を満たす奏行可能解の集合は!の有界 集合を構成しているが，集命に念まれる実行叮能解は， 集合に含まれる任意のいくつかの点 (実行川能解) $\left\{x_{i j}{ }^{(k)}\right\},\left\{y_{i}{ }^{(l)}\right\}$ の 1 次凸結合で表わすことができる。

すなわち, 任意の実行可能解における変数 $x_{i j}$ および $y_{i}$ は, 次のように $K$ 種の実行可能解の変数 $x_{i j}{ }^{(k)}$ お よび $L$ 種の実行可能解 $y_{i}{ }^{(l)}$ を用いて次のように表わ される。

$$
\begin{aligned}
& x_{i j}=\sum_{k=1}^{K} \lambda^{(k)} x_{i j}{ }^{(k)} \\
& (i=1,2, \cdots, m ; j=1,2, \cdots, n) \\
& \sum_{k=1}^{K} \lambda^{(k)}=1 \text {. } \\
& y_{i}=\sum_{l=1}^{L} \mu^{(l)} y_{i}{ }^{(l)} \quad(i=1,2, \cdots, m) \cdots \\
& \sum_{l=1}^{L} \mu^{(l)}=1
\end{aligned}
$$

さらに, 式 (3)，(4) は次のように表わされる。

$$
\begin{aligned}
& z= \sum_{k=1}^{K}\left(\sum_{i=1}^{m} \sum_{j=1}^{n} c_{i j} x_{i j}{ }^{(k)}\right) \lambda^{(k)} \\
&+\sum_{l=1}^{L}\left(\sum_{i=1}^{m} R_{i} y_{i}{ }^{(l)}\right) \mu^{(l)} \rightarrow \min . \cdots \cdots \cdots \cdots \\
& \sum_{k=1}^{K}\left(\sum_{j=1}^{n} x_{i j}{ }^{(k)}\right) \lambda^{(k)}+\sum_{l=1}^{L}\left(-A_{i} y_{i}\right) \mu^{(l)}=0 . .
\end{aligned}
$$

ここで,

$$
\begin{aligned}
& z_{1}{ }^{(k)}=\sum_{i=1}^{m} \sum_{j=1}^{n} c_{i j} x_{i j}{ }^{(k)} \\
& z_{2}{ }^{(l)}=\sum_{i=1}^{m} R_{i} y_{i}{ }^{(l)} \\
& \xi_{i}^{(k)}=\sum_{j=1}^{n} x_{i j}{ }^{(k)} \quad(i=1,2, \cdots, m) \\
& \eta_{i}{ }^{(l)}=-A_{i} y_{i}(i=1,2, \cdots, m)
\end{aligned}
$$

と扩くと, 式 (9)，(10) は次のようになる。

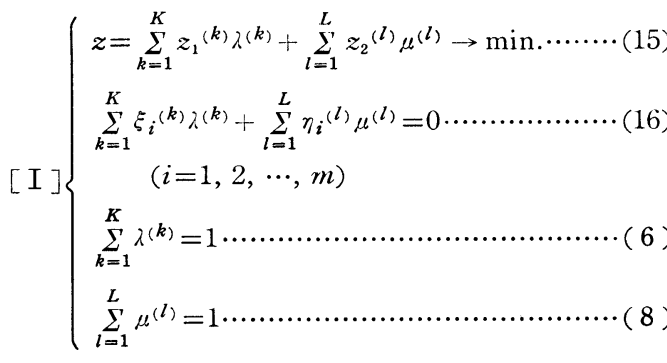

このように上式で表わされる関係は，式 (2)の実行叮 能な代替案の集合が満たすべき要件を表わしていること がわかる。

以上で, 導水路網計画とダム群の計画の代替案がモデ ルにおいてどのような関係を有するかについて明らかに してきた。次に，これらの代替案の組合せによって求め られる全体計画が最適計画を構成するための条件につい て述べることにする。
さて, 全体での最適解が満たすべき条件は, 上記の主 問題 [I ] が次の条件を渾たすことと同值である。すな わち, 問題 [I ] のようにLPによって定式化された場 合, 基底行列が次の条件を満たせば, 最適解が得られて いる。

$$
\begin{aligned}
& \bar{z}_{1}{ }^{(k)}=z_{1}{ }^{(k)}-\Pi \boldsymbol{v}_{1}{ }^{(k)} \geq 0 \text { for all } k \\
& \bar{z}_{2}{ }^{(l)}=z_{2}{ }^{(l)}-\Pi \boldsymbol{v}_{2}{ }^{(l)} \geqq 0 \text { for all } \\
& \text { ここで, } v_{1}{ }^{(k)}, v_{2}{ }^{(l)} \text { は, } \\
& v_{1}{ }^{(k)}={ }^{t}\left[\xi_{1}{ }^{(k)} \xi_{2}{ }^{(k)} \cdots \xi_{m}{ }^{(k)} 10\right] \\
& \boldsymbol{v}_{2}{ }^{(l)}={ }^{t}\left[\eta_{1}{ }^{(l)} \eta_{2}{ }^{(l)} \cdots \eta_{m}{ }^{(l)} 001\right]
\end{aligned}
$$

をまた $\boldsymbol{\Pi}$ は基底に対応する 1 組のシンプレックス剩 数からなるべクトルを表わしている。すなわち,

$$
\boldsymbol{I}=\left[I_{1}, \Pi_{2}, \cdots, \Pi_{i}, \cdots, \Pi_{m+2}\right]
$$

なお主問題においては，ダムのインデックス $i$ に関す る制約条件の数が $m$ 個， $\lambda, \mu$ に関して各 1 個, 垶 $(m+$ 2) 個の制約条件が存在するので，基底行列は $(m+2) \times$ $(m+2)$ の大きさになる。しかし, 式 (6), (8) および (16) における $(m+2)$ 個の制約条件は 1 次独立でない ので, 主問題を構成する制約条件のうちから $\lambda, \mu$ に対応 する列以外の任意の 1 個を省くことが必要になる。すな わち主問題の基底解のランクは $(m+1)$ となるから, そ れに対応するシンプレックス㮃数の数も $(m+1)$ とな る。したがってインデックスを適当にならびかえて主問 題の基底解と基底行列を行列表示すると次のように表わ される。

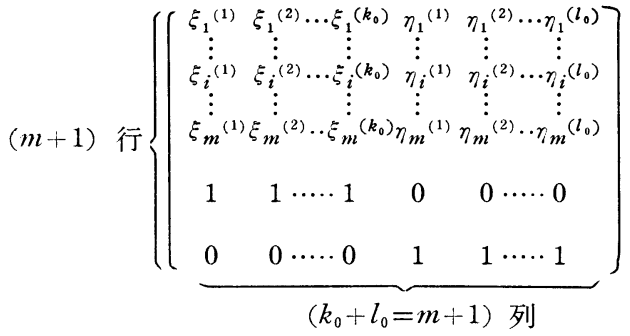

$$
\begin{aligned}
& \left.\cdot\left[\begin{array}{c}
\lambda^{(1)} \\
\lambda^{(2)} \\
\vdots \\
\lambda^{\left(k_{0}\right)} \\
\mu^{(1)} \\
\mu^{(2)} \\
\vdots \\
\mu^{\left(l_{0}\right)}
\end{array}\right)=\left(\begin{array}{c}
0 \\
0 \\
\vdots \\
0 \\
1 \\
1 \\
\vdots \\
1
\end{array}\right)\right\}(m+1) \text { 行 }
\end{aligned}
$$

さて式 (17)，(18）が満たされるかどうかを調バるた めには，まず $\bar{z}_{1} ， \bar{z}_{2}$ の最小值を求めるとともに, 次に そのうちどちらか小さい方が非負であることを調バるこ とが必要である。いま, 最適解かどうかを調べるための 条件を導くために，まず $\bar{z}_{1}{ }^{(k)}, \bar{z}_{2}{ }^{(l)}$ を次のように書き 換える。すなわち,

$$
\bar{z}_{1}^{(k)}=\sum_{i=1}^{m} \sum_{j=1}^{n} f_{i j} x_{i j}{ }^{(k)}-\Pi_{m+1}
$$




$$
\bar{z}_{2}^{(l)}=\sum_{i=1}^{m} g_{i} y_{i}{ }^{(l)}-\Pi_{m+2}
$$

$$
\text { ここで, }
$$

$$
\begin{aligned}
& f_{i j}=c_{i j}-I I_{i} \cdots \\
& g_{i}=R_{i}+I_{i} A_{i}
\end{aligned}
$$

いま，式（21），(22）より表わされる $\bar{z}_{1}{ }^{(k)}, \bar{z}_{2}{ }^{(l)}$ の 最小值を計算するためには, この段階では定数項である $I_{m+1}, I_{m+2}$ を省いて行なってもよいので, ここでは, この問題を次のような $[$ II $],[$ III $]$ の問題に書き表わす ことにする。すなわち，

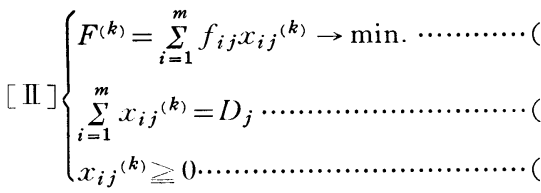

$$
\begin{aligned}
& {[\text { III }]\left\{\begin{array}{l}
G^{(l)}=\sum_{i=1}^{m} g_{i} y_{i}{ }^{(l)} \rightarrow \min . \cdots \ldots \ldots \ldots \ldots \ldots \\
\left.\sum_{i=1}^{m} A_{i} y_{i}{ }^{(l)}=I\right) \ldots \ldots \ldots \ldots \ldots \ldots \ldots \ldots \ldots \ldots \\
0 \leqq y_{i}{ }^{(l)} \leqq 1 \\
0 . \ldots \ldots \ldots \ldots \ldots \ldots \ldots \ldots \ldots \ldots
\end{array}\right.}
\end{aligned}
$$

次に，上式で表わされる 2 つの LP の問題 $[$ III $],[$ III $]$ の最適解 $F^{\left(k^{*}\right)}, G^{\left(l^{*}\right)}$ とそのときのシンプレックス剩数 $I_{m+1}, I_{m+2}$ を用いて $\bar{z}_{1}{ }^{(k)}, \bar{z}_{2}{ }^{(l)}$ を計算することによ

り, 次式で定義される $H$ の值を求める。

$$
H=\min \left(\bar{z}_{1}{ }^{(k)}, \bar{z}_{2}{ }^{(l)}\right)
$$

このとき最適かどうかの判定条件は次式で表わされ る。

$$
H \geqq 0
$$

このように, 問題 $[\mathrm{II}],[\mathrm{III}]$ は主問題 $[\mathrm{I}]$ を新た に構成していくために用いられるため, ここでは問題 [II ], [III] を主問題に対する「従問題」と呼ぶことにす る。

\section{（2）主問題の解の改善のプロセス}

いま，上記のようにして求めた $H$ は，最適解の場合 以外には，一般には式（32）を満たさない。すなわち，

$$
H<0
$$

であるときは，現在の $H$ の值を与えている $k^{*}$ または $l *$ で代表される実行可能解を新たに主問題に加えるこ とにより, 次の段階の主問題を構成して解いていくこと になる。すなわち，そこで選ばれた実行可能解によって 主問題の基底を構成するとともに，シンプレックス法に よりピボットタームを見出して, 基底から追い出される 実行可能解を決めればよいことになる。このようにして 新しい主問題における最適な基底行列が構成されたなら ば，これに対して新たなシンプレックス剩数ならびにそ れを用いて $\bar{z}_{1}{ }^{(k)}, \bar{z}_{2}{ }^{(l)}, H$ が計算できる。 $H$ が計算で きたならば，この新しい $H$ が式 (32) を満たすときに, 全体における最適解が得られたことになるが，もし満た
されなければ，上述と同様の手順を踏んで次のステップ に進む。このようにしてディコンポジションの原理によ る解法のプロセスは, 主問題 $\rightarrow$ 従問題 $\rightarrow$ 主問題といら ように条件式（32）が満たされるまで継続する。これら のステップを実行するためにはまずステップ1において 初期主問題を設定する必要がある。そのために従問題 $[$ II $],[$ III $]$ より総計 $(m+1)$ 個の代替案を選び主問題の 初期実行可能解を決定する。その方法はいろいろ考えら れるが，実行可能な解を比較的容易に求めるためには， 次の方法によることにする。すなわち, まず, 全体にお ける任意の 1 つの実行可能解を求める。この解を導水路 に関する部分とダムに関する部分の 2 つ分割し, これ を主問題を構成する代替案とする。またこの 2 つの代替

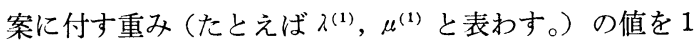
とする。すなわち $\lambda^{(1)}=1, \mu^{(1)}=1$ とする。さらに残り の $(m-1)$ 個の代替案を従問題 [II $],[$ III $]$ より選ぶと ともに, これらの代替案に付す重みの值を 0 ときめる。 すなわち $\lambda^{(k)}=0 \quad\left(k=2,3, \cdots, k_{0}\right)$ かつ $\mu^{(l)}=0 \quad(l=2$, $\left.\cdots, l_{0}\right)$ とする。このようにすれば, 初期主問題は機械 的に実行可能になり, 結局最初に選んだ全体における実 行可能解が選ばれることになる。ここで, ディコンポジ ションによる解法のプロセスを示すと図一2 のフローチ ヤートのようである。

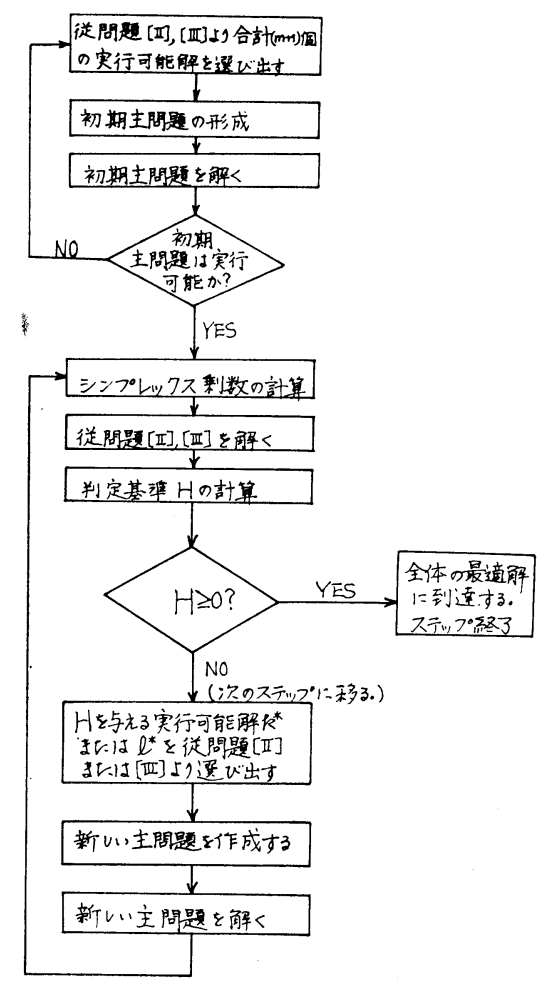

図一2 ディコンポジションの原理による解法のプロセス 
（3）ティコンポジションによる解法のプロセスと総 合調整過程との関係

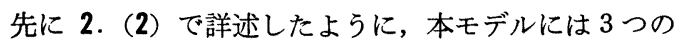
機能が組み込まれている。すなわち, (1)ダムの建設位置 の選定と規模を計画する機能, (2)建設されるダムと需要 地とを結ぶ導水路網の位置・規模を計画する機能，(3) (1),(2) の計画を合理的に調整する機能の 3 つである。そ してこれらの機能は上述したディコンポジションの原理 とその解法により合理的に説明することができる。すな わち, 式 (25)，(26)，(27) で表わされる従問題 [II], ならびに式 (28)，(29)，(30) で表わされる従問題 [III] は，それぞれ上記の(2)，(1)の機能に対応していると考え られる。このようにして各個に独立に選び出された各代 替案は, 式 (15), (16), (6), (8) で表わされる主問題 [I ] を解くことにより, 全体において実行可能解でか つ建設費の総和が最小になるような計画へと調整されて いくとともに, 各計画の相対的な重み（構成度）を示す $\lambda^{(k)}, \mu^{(l)}$ なる值が求められる。もし最適解が得られて いない場合には, 新たに [II ], [III ] の従問題から別の 代替案を選び出して新しい主問題を作成し, 再度 $\lambda^{(k)}$, $\mu^{(l)}$ を求める。したがってこの主問題は, (1)と(2)の機能 を総合調整する計画機能すなわち(3)を代表しているもの と考えてよい。そしてそこにおける $\lambda^{(k)}, \mu^{(l)}$ の值およ びその変化の様子は，その調整過程を具体的に示す $1 つ$ のファクターと考えることができる。このように，本モ デルにディコンポジションの原理とその解法を適用すれ ば, モデルの作成上で意図する 3 つの機能の組み込みと その分析が可能になる。

\section{4. 兵庫県の広域利水計画における実証的分 析}

\section{（1）兵庫県の利水問題の概要}

兵庫県は, その県域内に大阪湾・瀬戸内沿岸と日本海 岸とをもつ水利用の観点からは特色のある県である。し かも大阪湾・瀬戸内沿岸は, 阪神工業地帯さらにはその 延長として播磨工業地帯などの重工業地帯が広がってい る。さらに神戸港とい5日本屈指の大港湾を抱え, 工業 ・商業における物資の流通など経済活動がきわめて活発 である。最近の企業の立地動向は, 成熟期にある阪神工 業地帯 (工業整備特別地区) を中心に展開しており, 特 に東播地区には阪神都市圏からの機械工業をはじめとす る都市型工業の分散立地が顕著である。また東播地区・ 阪神臨海地区の埋立地へは, 流通加工型企業の進出がめ ざましい。さらに阪神地区や明石・加古川などの一部の 東播地区のらちでは, 阪神地域の諸都市との交通の便の よさ, 時間距離の短縮, 都市内地域・近郊住宅地の地価 の高騰などの影響を受けて, 宅地化が急激に進んでい る。このような背景のもとに年々急激な水需要の増大が 発生し, 将来, 阪神・播磨地域の一部では深刻な水不足 が発生するものと予測されている。特に神戸・西宮・尼 崎などの阪神地域は, 現在, 武庫川・淀川水系の一環に あるが, 昭和 60 年時点で, 淀川の水供給能力が限界に 達すると考えられるので, 他の地域からの分水を考慮す る必要がある。また日本海側の但馬地域は, 将来予定さ れている地域開発・工業開発を含めても円山川水系の開 発量にはかなりの余裕があると算定されている。さらに は, 1 年間の降雨特性をみると, 日本海側は冬期には降 雪などの関係で比較的雨量に恵まれているのに対して, 瀬戸内沿岸地帯は冬期は賽雨のため, 日本海側と瀬戸内 側では水の偏在が生じている。このように日本海側と瀬 戸内側では, 水が降雨の面でも, 需要の面でも偏在して いる。したがってて山川水系の開発量の一部を阪神・播 磨地域に分水する必要性が生じてくるわけである。

\section{表一1 上水道用水・工業用水の需要水量および新規需要量}

(単位: $1000 \mathrm{~m}^{3} /$ 年)

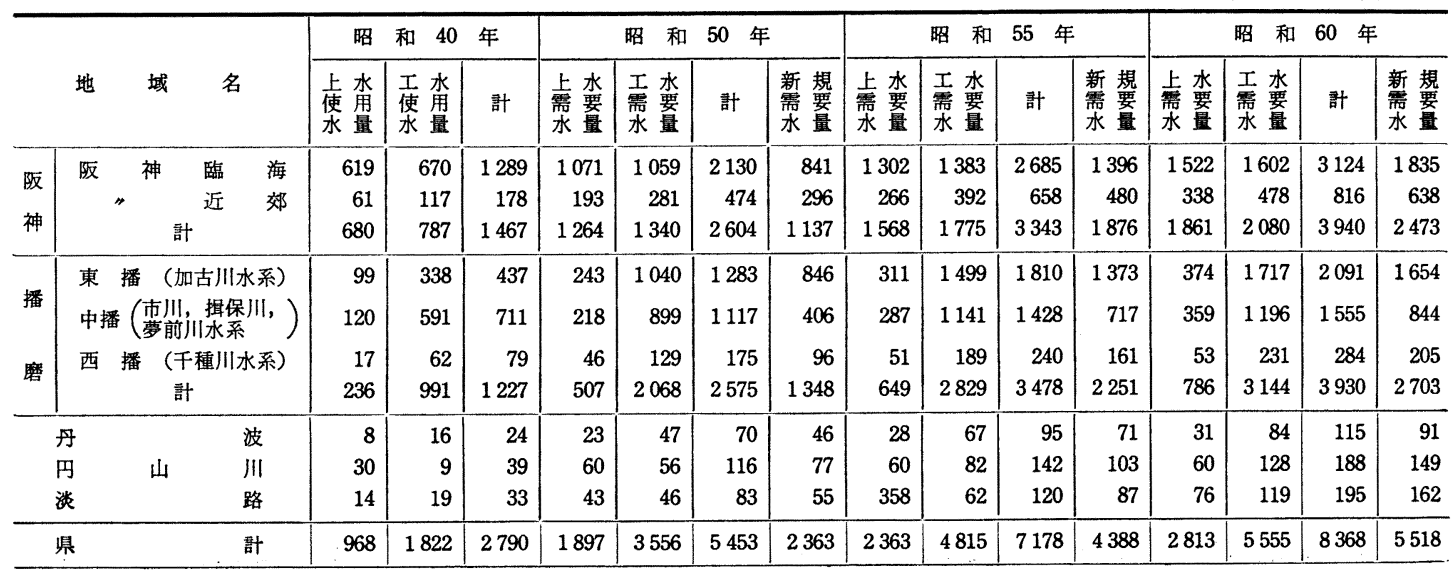


このよらな考え方に基づいて兵庫県

表一3 蒴水トンネルエ事费

は，各地域の地域開発の動向と将来の方 向性とを関連うけることにより，今後の 水資源開発の構想を打ち出している。

さて以下では, これらの事項を考慮に 入れて, 円山川水系と加古川水系，市川 水系への分水路, さらには将来も比較的 水源開発にゆとりのある播磨地域の千種 川，揖保川などの諸河川の間の導水路な どを含めた兵庫県広域利水施設のパター

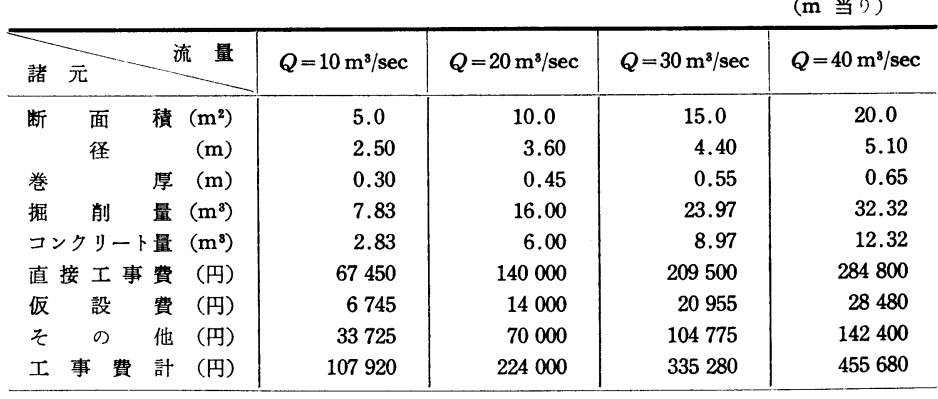

ンを設定するとともに，広域利水計画をダム群と導水路 網の建設計画としてとらえ考察をすすめることにする。

\section{（2）各地区の需要量の算定}

各地区の需要量は「兵庫県開発計画案 概 要 (兵 庫 県 昭和 45 年 7 月)」に基づき，県企画課水資源対策室が 算定した結果を用いる。それを表一1に示した。なお表 -2 には表一1 で示された将来需要量を各水系ごとに割 りふってある。その際, 東播地区の新規需要量は, 加古 川に，西播地区は千種川に，但馬地区は円山川に依存さ せる。中播地区は現在の給水実績比（上水のみ）で，揖 保川，夢前川，市川に割りふって計算した。これは各河 川の下流に位置する各需要地注，末端においては従来ど おりもよりの河川に依存すると考えたものである。した がって末端の配水管の建設は，この方針にのっとって行 なわれる。

\section{（3）導水路網のルート選定と建設単価の算定}

導水路は水道における配水管のような性格をもつもの であり，道路に沿，て配置することも考えられる。しか し供給量と需要量との関係から推定すると，その通水量 は $10 \mathrm{~m}^{3} / \mathrm{sec}$ 以上となる所もある。管内流速を $2.0 \mathrm{~m}^{3} /$ sec とすれば，その径は $2.5 \mathrm{~m}$ となり，このような大 規模な管路を埋設することは，現在の市街地の状沉から 判断すると，かなり困難であると考えねばならない。ま た管路の破損などによる被害は，交通その他に大きな影 響を与えると思われる。また導水路はある水系から他の 水系に，さらに水系をこえて他の水系に水を導入する必 要があり得る。このような条件を满足させるためには， トンネル配水池的な 性格の設備が適当で あると考えられる。 このよらな観点から 導水路は地山にトン ネルとして設置する ことにした。なお， 導水路の建設単価の
表一4 水管橋工事費

(m 当り)

\begin{tabular}{rr|r|r|r|r}
\hline 諸元 & 流量 & $Q=10 \mathrm{~m}^{8} / \mathrm{s}$ & $Q=20 \mathrm{~m}^{3} / \mathrm{s}$ & $Q=30 \mathrm{~m}^{3} / \mathrm{s}$ & $Q=40 \mathrm{~m}^{8} / \mathrm{s}$ \\
\hline 徍 & $(\mathrm{mm})$ & 2500 & 3600 & 4400 & 5100 \\
$t$ & $(\mathrm{~mm})$ & 12 & 17 & 20 & 23 \\
$W$ & $(\mathrm{~kg} / \mathrm{m})$ & 743.4 & 1516 & 2180 & 2906 \\
工事費 & $($ (P) & 594400 & 1212800 & 1744000 & 2324800 \\
\hline
\end{tabular}

表-5 円山川分水路事業費

$\left(6.0 \mathrm{~m}^{8} / \mathrm{sec}\right)$

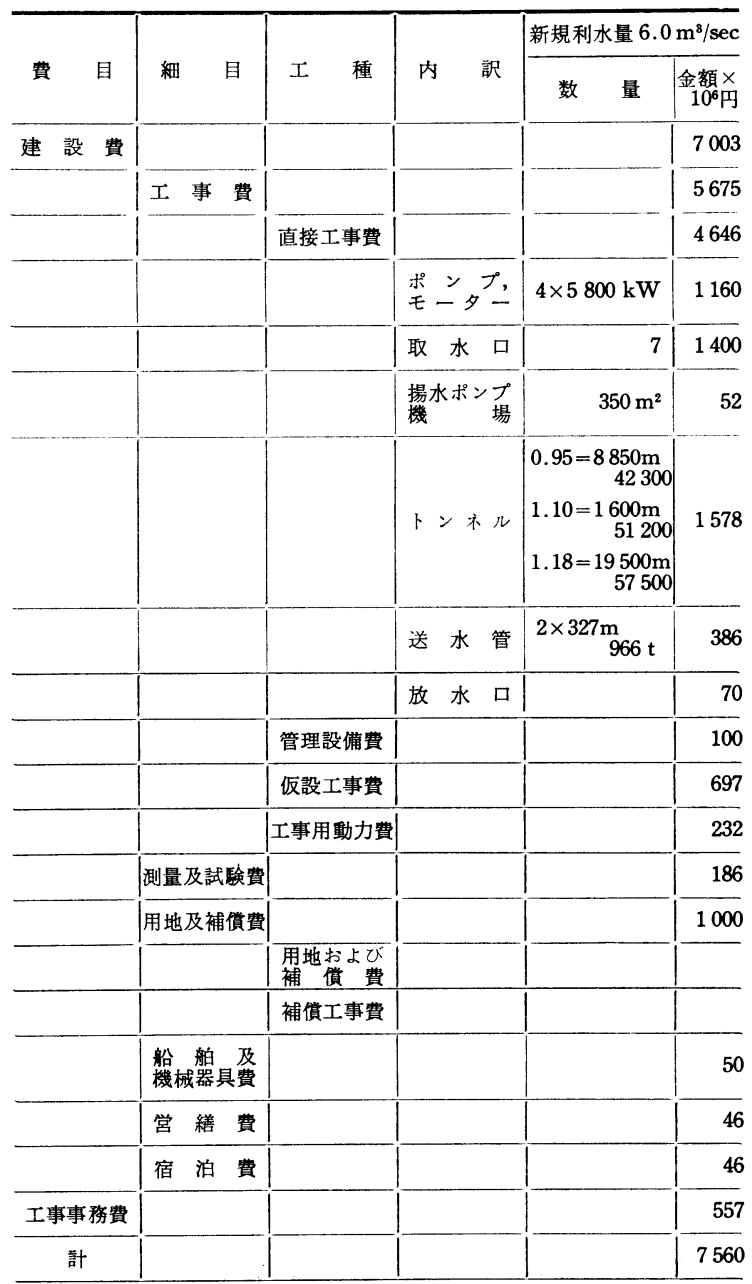




\section{表一6 円山川分水路事業费}

\begin{tabular}{|c|c|c|c|c|c|}
\hline \multirow[b]{2}{*}{ 歧 } & \multirow[b]{2}{*}{ 細 日 } & \multirow[b]{2}{*}{ I. 秏 } & \multirow[b]{2}{*}{ 内 訳 } & \multicolumn{2}{|c|}{ 新規利水量 $8.0 \mathrm{~m}^{3} / \mathrm{sec}$} \\
\hline & & & & 数 量 & $\begin{array}{l}\text { 金額 } \times \\
10^{6} \mathrm{PJ}\end{array}$ \\
\hline 建 設 費 & & & & & 8390 \\
\hline & 工 事 費 & & & & 6996 \\
\hline & & |直接工事費 & & & 5747 \\
\hline & & & $\begin{array}{l}\text { ポンプ, } \\
\text { モーター }\end{array}$ & $4 \times 9300 \mathrm{~kW}$ & 1860 \\
\hline & & & 取 水口 & 7 & 1400 \\
\hline & & & $\begin{array}{l}\text { 揚水ポンプ } \\
\text { 場 }\end{array}$ & $400 \mathrm{~m}^{3}$ & 60 \\
\hline & & & トンネル & $\left|\begin{array}{rl}0.95= & 8850 \\
42300 \\
1.10= & 1600 \\
51200 \\
1.32= & 19500 \\
70500\end{array}\right|$ & 1831 \\
\hline & & & 送 水 管 & \begin{tabular}{|}
$2 \times 395 \mathrm{~m}$ \\
$1315 \mathrm{t}$
\end{tabular} & 526 \\
\hline & & & 放水口 & 7 & 70 \\
\hline & & 管理設備費 & & & 100 \\
\hline & & 仮設工事費 & & & 862 \\
\hline & & 工事用動力費 $\mid$ & & & 287 \\
\hline & 測量及試験費| & & & & 230 \\
\hline & 用地及補償費 & & & & 1000 \\
\hline & & $\begin{array}{l}\text { 用地拉よU } \\
\text { 補 償 費 }\end{array}$ & & & \\
\hline & & 補償工事費 & & & \\
\hline & 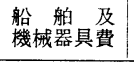 & & & & 50 \\
\hline & 営 繥 費 & & & & 57 \\
\hline & 宿 泊 費 & & & & 57 \\
\hline 工事事務費 & & & & & 670 \\
\hline 苦 & & & & & 9060 \\
\hline
\end{tabular}

算定にあたって用いた各種の概算単価の一部を表一3 か ら表一4 に掲げた。また，円川川分水路事業費ならびに 建設単価のらち, いくつかを表一5 と表一6に示した。

\section{（4）ダムの建設費の算定}

ダムの建設費の算定を, 千種川水系, 揖保川水系, 市 川水系, 加古川水系ならびに円山川水系のそれぞれに対 して行なった。その結果, 新規開発量 (ダムの規模すな わち容量に相当すると考えてよい）と開発費用との間に は線形性がほぼ認められることがわかた。(ここでは， 円山川水系開発費の算定結果を 図一3に例示した。）し たがって以下では, 両者の関係を線形とみなして計算を 進めることとし，これらを整理して表一7 に示した。

\section{（5）モデルの修正}

モデルの対象となる広域利水計画を模式化すれば, 図 一4のようになる。さて河道をそのまま用いるルート

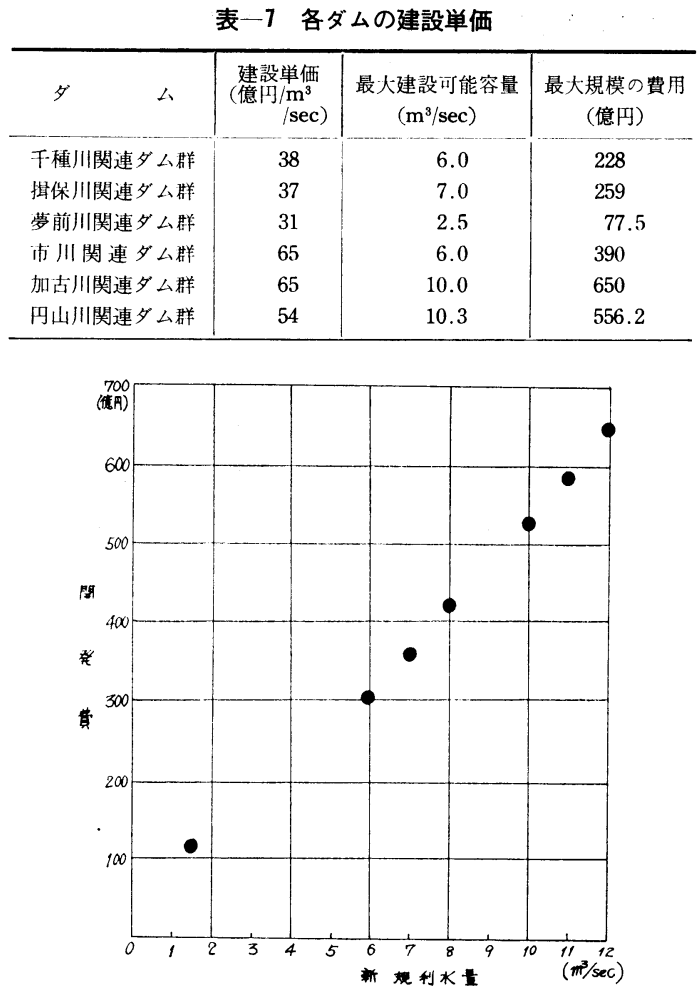

\section{図--3 円山川水系開発費と新規利水量との関係}
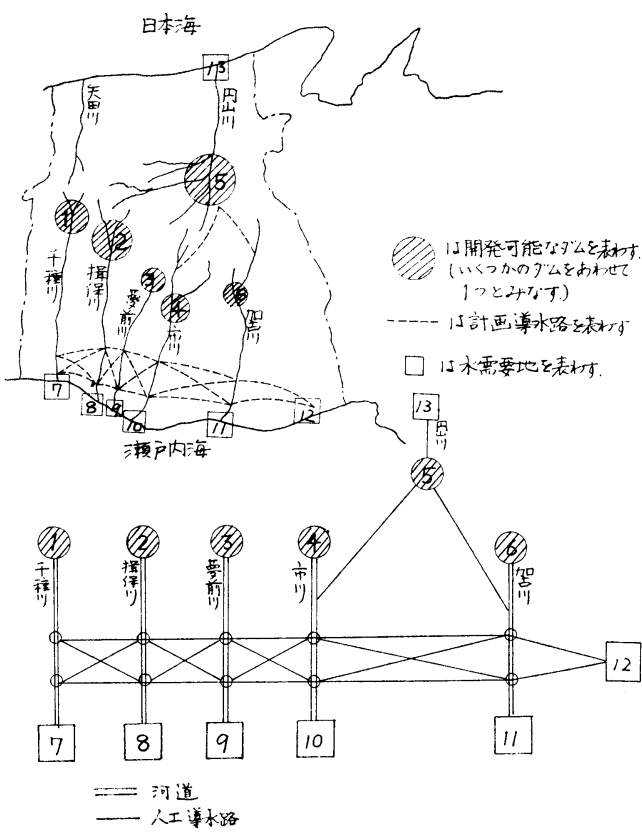

図-4 兵庫県の広域利水計画の数学モデル化の模式図

は, 建設費を 0 とみなすと, 計算上几長なルートが存在 することになるので，これらの径路を省くと，模式図は 図一5 のように簡単になる。なお円山川下流域の水需要 地には, (5)の供給可能量からあらかじめ (5) に依存する 


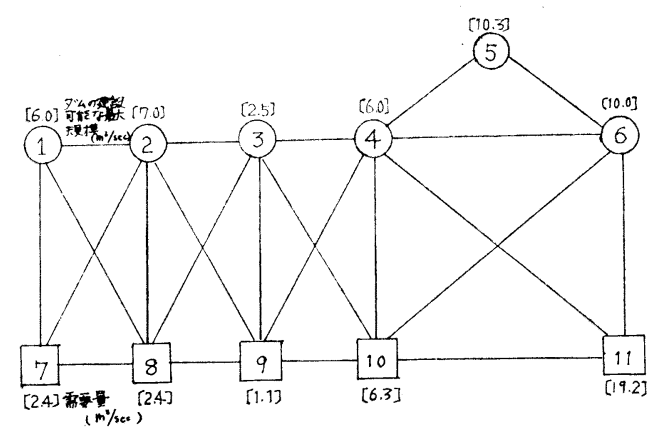

図５モデルの模式図（修正したもの）

需要量分を差し引いておくここにより，この径路を省略 することができる。またルート (6-12) とルート（1112）とは建設単価が同一なので，このルート（6-12)， (11-12) は最適計算上尣長になる。そこであらかじめ[12] の需要量を111に含めて計算することにすれば, 需要地囵 およびルート (6-12)，(11-12) は省略できる。以下の計 算では，これらを省略して計算を進めることにした。

また，ここで用いる広域利水システムにおいては，導 水路が中継地点を含むネットワーク構造になっているの で，前述のモデルに対しては以下のような修正を必要と する。

いま，建設予定のダムの最大個数を $m$, 中継地の数を $p$, 需要地の数を $n$ とするならば, モデルの定式化は以 下のとおりになる。なおこの場合, 需要地・供給地・中 継地を問わず，すべての地点を供給地点として考えると 同時に, 需要地点であると考える。ただし実際のダムの 場合には, その供給量を $A_{i} y_{i}$ とおき, 需要地と中継地 の供給量は 0 とする。また需要地の需要量は $D_{i}$, ダム と中継地の需要量は 0 とする。ここで, サフィックス $i$, jは以下において,

$$
i, j=\left\{\begin{array}{l}
1,2, \cdots, m: \text { ダ } \text { 厶 } \\
m+1, \cdots, m+p: \text { 中継地 } \\
m+p+1, \cdots, m+p+n: \text { 需要地 }
\end{array}\right.
$$

とする。

このよらに考えるとモデルは次のように修正される。 すなわち,

目的関数 :

$$
z=\sum_{i=1}^{m+n+p} \sum_{j=1}^{m+n+p} c_{i j} x_{i j}+\sum_{i=1}^{m} R_{i} y_{i} \rightarrow \min . \cdots
$$

制約条件：

$$
\begin{aligned}
& \sum_{j=1}^{m+p+n} x_{i j}-A_{i} y_{i}=0 \quad(i=1,2, \cdots, m) \cdots \cdots \cdots(35) \\
& \sum_{j=1}^{m+p+n} x_{i j}=0 \quad(i=m+1, \cdots, m+p+n) \cdots \cdots(36) \\
& \sum_{i=1}^{m+p+n} x_{i j}=0 \quad(j=1,2, \cdots, m, m+1, \cdots m+p)
\end{aligned}
$$

$$
\sum_{i=1}^{m+p+n} x_{i j}=D_{j}(j=m+p+1, \cdots, m+p+n)
$$

ここで任意の奏行可能解はそれぞれの解集合 $\left\{x_{i j}{ }^{\left({ }^{(k)}\right)}\right\}$ および $\left\{y_{i}{ }^{(l)}\right\}$ の端点の 1 次兄結合によ，て表わされる ことはすでに述べたとおりである。すなわち,

$$
\begin{aligned}
& x_{i j}=\sum_{k=1}^{K} \lambda^{(k)} x_{i j}{ }^{(k)} \\
& \sum_{k=1}^{K} \lambda^{(k)}=1 \\
& y_{i}=\sum_{l=1}^{L} \mu^{(l)} y_{i}{ }^{(l)} \\
& \sum_{l=1}^{L} \mu^{(l)}=1 \text {. }
\end{aligned}
$$

式 (39)，(41)を式 (34) に代人すると, 目的関数は,

$$
z=\sum_{k=1}^{K} z_{1}{ }^{(k)} \lambda^{(k)}+\sum_{l=1}^{L} z_{2}{ }^{(l)} \mu^{(l)} \rightarrow \min .
$$

ここで,

$$
\begin{aligned}
& z_{1}{ }^{\prime(k)}=\sum_{i=1}^{m+n+p} \sum_{j=1}^{m+n+p} c_{i j} x_{i j}{ }^{(k)} \\
& z_{2}{ }^{(l)}=\sum_{i=1}^{m} R_{i} y_{i}{ }^{(l)}
\end{aligned}
$$

のように表わされる。

また，式 (39)，(41）を用いると式 (35) は次式のよ うに表わされる。

$$
\begin{gathered}
\sum_{k=1}^{K} \xi_{i}{ }^{\prime(k)} \lambda^{(k)}+\sum_{l=1}^{L} \eta_{i}{ }^{(l)} \mu^{(l)}=0 \cdots \\
(i=1,2, \cdots, m)
\end{gathered}
$$

\begin{tabular}{|c|c|c|}
\hline 記号 & 地 域 名 & $\begin{array}{c}\text { 需要量 } \\
\left(\mathrm{m}^{3} / \mathrm{sec}\right)\end{array}$ \\
\hline 7 & 千種川下流域 & 2.4 \\
\hline 8 & 捍保川下流域 & 2.4 \\
\hline 9 & 夢前川下流域 & 1.1 \\
\hline 10 & 市川下流域 & 6.3 \\
\hline 11 & 加古川下流域 & 19.2 \\
\hline 12 & 神户地域 & 0.0 \\
\hline
\end{tabular}

ここに $\xi_{i}{ }^{\prime(k)}$, はダム $i$ から隣接する需要地または中 継地間を結ぶ導水路に配分される水量の総和を表わし, 式 (13) $の \xi_{i}{ }^{\left({ }^{k}\right)}$ に相等する。

\section{(6) 結果の考察}

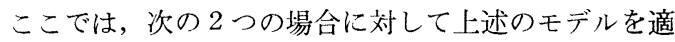
用し, 分析を行なった。

ケース I : 神戸地域には, 分水を行なわない場合。(し たがって計算上は, 加古川下流城の需要量を $19.2 \mathrm{~m}^{3} /$ sec とし，神戸地域への分水はこれを含めない。）この 場合は, 地域全体の開発可能量 $41.8 \mathrm{~m}^{3} / \mathrm{sec}$ に対し, 総

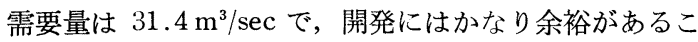
とが特徴である。このケースで用いた各水系の下流域の

\begin{tabular}{r|c|r}
\multicolumn{3}{|c}{ する場合 (ケース II) } \\
\hline 記号 & 地 域 名 & $\begin{array}{c}\text { 需要量 } \\
\left(\mathrm{m}^{8} / \mathrm{sec}\right)\end{array}$ \\
\hline 7 & 千種川下流域 & 2.4 \\
8 & 揖保川下流域 & 2.4 \\
9 & 夢前川下流域 & 1.1 \\
10 & 市川下流域 & 6.3 \\
11 & 加古川下流域 & 19.2 \\
12 & 神 戸 地 域 & 5.0 \\
\hline
\end{tabular}


需要量を表一8 (a) に示した。

ケース III : 神戸地域に $5 \mathrm{~m}^{3} / \mathrm{sec}$ の分水を行なら場合 (したがって計算上は, 加古川下流域の需要量 $5 \mathrm{~m}^{3} / \mathrm{sec}$ を含めて, $24.2 \mathrm{~m}^{3} / \mathrm{sec}$ とする。）この場合は, 地域全体 の開発可能量 $41.8 \mathrm{~m}^{3} / \mathrm{sec}$ に対し, 総需要量は $36.4 \mathrm{~m}^{3}$ / sec で開発量がかなりひっ迫していることが特徴であ る。このケースで用いた各水系下流域の需要量を表一8 (b) に示した。

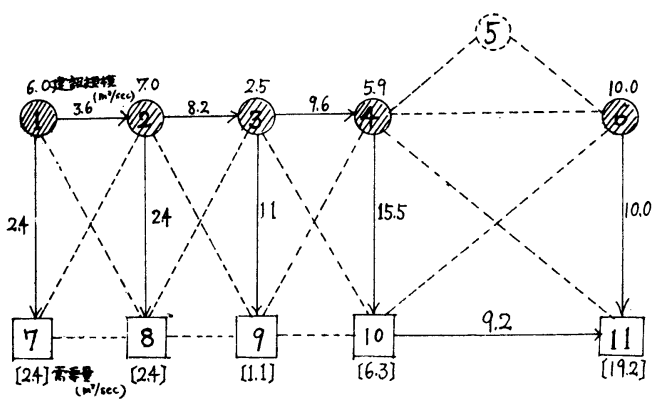

図一6（a）主問題の初期実行可能解（ケース I）

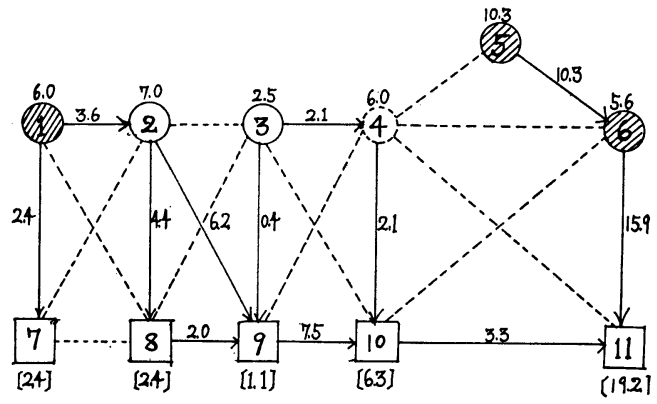

図一6（b） 主問題の最適解（ケース I) a) 計算結果

ケースI およびケース II の主問題の初期実行可能解 を図一6 (a) および 図一7 (a) に示した。またこれらの ケースの最適解を図一6 (b) および図一7 (b) に示した。 これらの最適解は，最適解を構成する 7 つの解を 表一9 および表一10 に示すような $\lambda^{(k)}, \mu^{(l)}$ の值を用いて重 みゔけして合成した結果求められたものである。また，

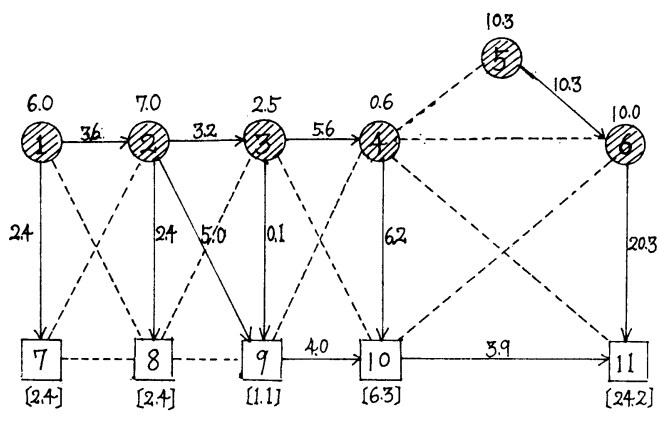

図-7（a） 主問題の初期実行可能解（ケース II）

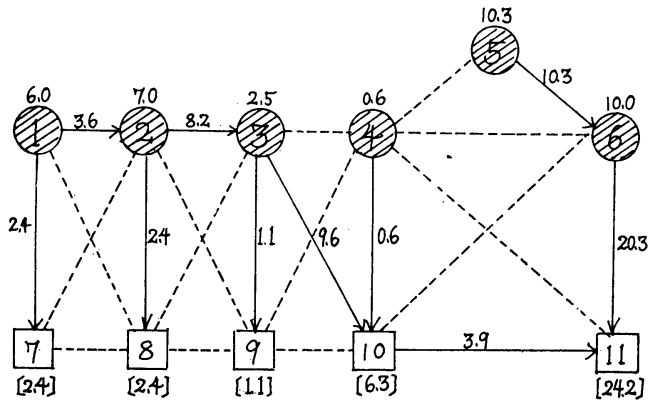

図一7（b）主問題の最適解（ケース II）

表一9 重み係数 $\lambda^{(k)}, \boldsymbol{\mu}^{(l)}$ のステップ綵り返しによる変化（ケース I）

\begin{tabular}{|c|c|c|c|c|c|c|c|c|c|c|c|c|c|c|c|c|}
\hline & $k, l 0$ 值 & 重办係数 & 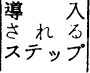 & $\begin{array}{c}\text { ステップ } \\
1\end{array}$ & $\begin{array}{c}\text { ステッフ } \\
2\end{array}$ & ステップ & ステッフ & $\begin{array}{c}\text { ステップ } \\
5\end{array}$ & $\begin{array}{c}\text { ステップ } \\
6\end{array}$ & ステップ & ステップ & ステップ & $\begin{array}{c}\text { ステップ } \\
10\end{array}$ & $\begin{array}{c}\text { ステップ } \\
11\end{array}$ & $\begin{array}{c}\text { ステッフ } \\
12\end{array}$ & $\begin{array}{c}\text { ステップ } \\
13\end{array}$ \\
\hline$\stackrel{l}{2}$ & 1 & $\mu^{(1)}$ & 1 & 1.0 & 1.0 & 1.0 & 1.0 & 0.761 & 0.517 & 0.141 & 0.131 & * & * & * & * & * \\
\hline 多公 & 2 & $\mu^{(2)}$ & 1 & 0.0 & 0.0 & 0.0 & 0.0 & 0.239 & 0.483 & 0.859 & 0.869 & 1.0 & 1.0 & 1.0 & 1.0 & 1.0 \\
\hline & 1 & $\lambda^{(1)}$ & 1 & 1.0 & 1.0 & 1.0 & 1.0 & * & * & * & * & * & * & * & * & $*$ \\
\hline & 2 & $\lambda^{(2)}$ & 1 & 0.0 & 0.0 & 0.0 & * & * & * & * & * & * & * & * & * & * \\
\hline & 3 & $\lambda^{(8)}$ & 1 & 0.0 & 0.0 & 0.0 & 0.0 & 0.743 & 0.508 & 0.012 & * & * & * & * & $*$ & * \\
\hline & 4 & $\lambda^{(4)}$ & 1 & 0.0 & * & * & * & * & * & * & * & * & * & * & * & * \\
\hline & 5 & $\lambda^{(5)}$ & 1 & 0.0 & 0.0 & * & * & * & * & * & * & * & * & * & * & * \\
\hline$k$ & 6 & $\lambda^{(6)}$ & 2 & & 0.0 & 0.0 & 0.0 & 0.104 & 0.142 & 0.212 & 0.213 & 0.202 & 0.172 & 0.172 & 0.172 & 0.172 \\
\hline & 7 & $\lambda^{(7)}$ & 3 & & & 0.0 & 0.0 & 0.076 & 0.145 & 0.318 & 0.320 & 0.199 & 0.140 & 0.075 & 0.075 & * \\
\hline 尊 & 8 & $\lambda^{(8)}$ & 4 & & & & 0.0 & 0.042 & 0.032 & * & * & * & * & * & $*$ & * \\
\hline & 9 & $\lambda^{(\theta)}$ & 5 & & & & & 0.030 & * & * & * & * & * & * & * & * \\
\hline 水 & 10 & $\lambda^{(10)}$ & 6 & & & & & & 0.171 & 0.337 & 0.341 & 0.367 & 0.338 & 0.274 & 0.274 & 0.274 \\
\hline 路 & 11 & $\lambda^{(11)}$ & 7 & & & & & & & 0.121 & 0.124 & 0.0 & 0.0 & 0.0 & * & * \\
\hline & 12 & $\lambda^{(12)}$ & 8 & & & & & & & & 0.0 & 0.092 & $*$ & * & * & * \\
\hline & 13 & $\lambda^{(18)}$ & 9 & & & & & & & & & 0.138 & 0.193 & * & * & * \\
\hline & 14 & $\lambda(14)$ & 10 & & & & & & & & & & 0.152 & 0.217 & 0.217 & 0.217 \\
\hline & 15 & $\lambda(15)$ & 11 & & & & & & & & & & & 0.263 & 0.263 & 0.263 \\
\hline & 16 & $\lambda(16)$ & 12 & & & & & & & & & & & & 0.0 & 0.0 \\
\hline & 17 & $\lambda(17)$ & 13 & & & & & & & & & & & & & 0.075 \\
\hline
\end{tabular}

*は基底から追い出されていることを示す。

フランクタ，まだ基底に導入されていないことを示す。 
表一10 重み係数 $\lambda^{(k)}, \mu^{(\iota)}$ のステップ綝り返しによる変化（ケース II）

\begin{tabular}{|c|c|c|c|c|c|c|c|c|c|c|c|c|}
\hline & $k, l$ の值 & 重及係数 & \begin{tabular}{|l|} 
繁入される \\
ステップ
\end{tabular} & $\underset{1}{\text { ステッフ }}$ & $\begin{array}{l}\text { ステッフ } \\
2\end{array}$ & $\begin{array}{c}\text { ステップ } \\
3\end{array}$ & ${ }_{4}^{\text {ステップ }}$ & $\begin{array}{c}\text { ステップ } \\
5\end{array}$ & $\begin{array}{c}\text { ステップ } \\
6\end{array}$ & $\begin{array}{c}\text { ステップ } \\
7\end{array}$ & $\underset{8}{\text { ステッフ }}$ & $\begin{array}{c}\text { ステッフ } \\
9\end{array}$ \\
\hline$l$ (夕ム) & 1 & $\mu^{(1)}$ & 1 & 1.0 & 1.0 & 1.0 & 1.0 & 1.0 & 1.0 & 1.0 & 1.0 & 1.0 \\
\hline \multirow{14}{*}{$k$ (等水路) } & 1 & $\lambda^{(1)}$ & 1 & 0.0 & * & * & * & $*$ & * & * & * & * \\
\hline & 2 & $\lambda^{(2)}$ & 1 & 1.0 & 1.0 & 0.100 & 0.100 & 0.100 & 0.100 & 0.100 & * & * \\
\hline & 3 & $\lambda^{(8)}$ & 1 & 0.0 & 0.0 & 0.065 & $0.07 \mathrm{I}$ & 0.091 & $*$ & $*$ & $*$ & $*$ \\
\hline & 4 & $\lambda^{(4)}$ & 1 & 0.0 & 0.0 & 0.0 & $*$ & * & * & * & $*$ & * \\
\hline & 5 & $\lambda^{(5)}$ & 1 & 0.0 & 0.0 & $*$ & * & * & * & * & * & * \\
\hline & 6 & $\lambda(6)$ & 1 & 0.0 & 0.0 & 0.383 & 0.383 & 0.359 & 0.048 & * & * & * \\
\hline & 7 & $\lambda(7)$ & 2 & & 0.0 & 0.057 & 0.056 & 0.058 & 0.089 & 0.090 & 0.090 & 0.101 \\
\hline & 8 & $\lambda^{(8)}$ & 3 & & & 0.421 & 0.394 & 0.394 & 0.346 & 0.328 & 0.328 & $*$ \\
\hline & 9 & $\lambda^{(\theta)}$ & 4 & & & & 0.0 & $*$ & $*$ & $*$ & $*$ & * \\
\hline & 10 & $\lambda^{(10)}$ & 5 & & & & & 0.0 & 0.058 & 0.056 & 0.056 & 0.062 \\
\hline & 11 & $\lambda^{(11)}$ & 6 & & & & & & 0.340 & 0.359 & 0.359 & 0.426 \\
\hline & 12 & $\lambda^{(12)}$ & 7 & & & & & & & 0.066 & 0.066 & 0.097 \\
\hline & 13 & $\lambda^{(13)}$ & 8 & & & & & & & & 0.100 & 0.221 \\
\hline & 14 & $\lambda(14)$ & 9 & & & & & & & & & 0.095 \\
\hline
\end{tabular}

*は基底から追い出されていることを示す。

フランクは、まだ基底に導入されていないことを示す。
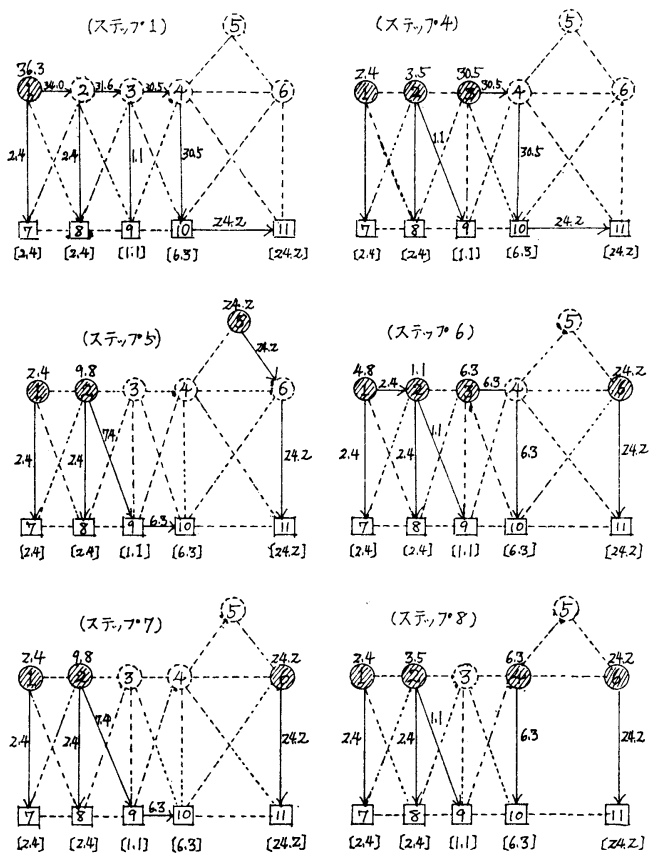

図一8 最逼解を構成する 6 つの代替案（算水路）（ケースII）

（）内はそれが最初に選ばれたステップを表わす

ケース II の最適解を構成する 7 つの実行可能解 (代替

案) のうち導水路の代替案 6 個を図一8 に示した。これ らの解は, ディコンポジションの原理による解法のプロ セスのいくつかのステップで選び出されたものであり, 単独では全体における実行可能解にならない。しかし各 ステップで選び出される解は, 前述のように重みづけさ れることによって，全体における新しい1つの実行可能 解を構成していくことになる。そして各ステップの主問 題で得られる全体における実行可能解は, それまでに得 られた従問題の解と新たに従問題より選び出される解を 用いて，全体としてさらに改善された実行可能解へと置

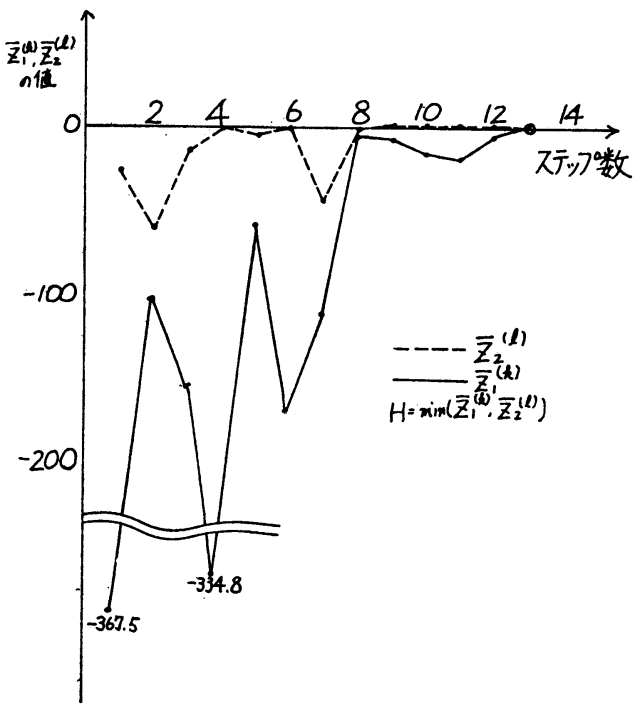

図一9 判定基準 $\bar{z}_{1}{ }^{(k)}, \bar{z}_{2}{ }^{(l)}, \boldsymbol{H}$ の変化（ケース I $)$

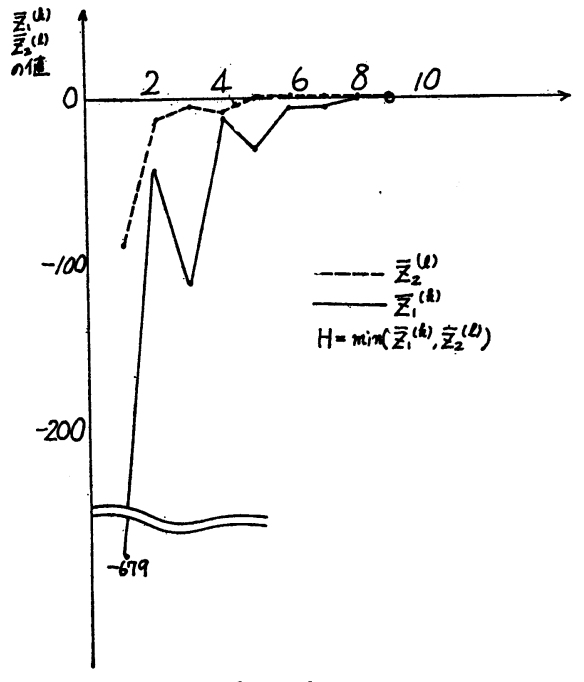

図-10 判定基準 $\overline{\boldsymbol{z}}_{1}{ }^{(k)}, \overline{\boldsymbol{z}}_{2}{ }^{(l)}, \boldsymbol{H}$ の変化 $(ケ-ス$ II $)$ 


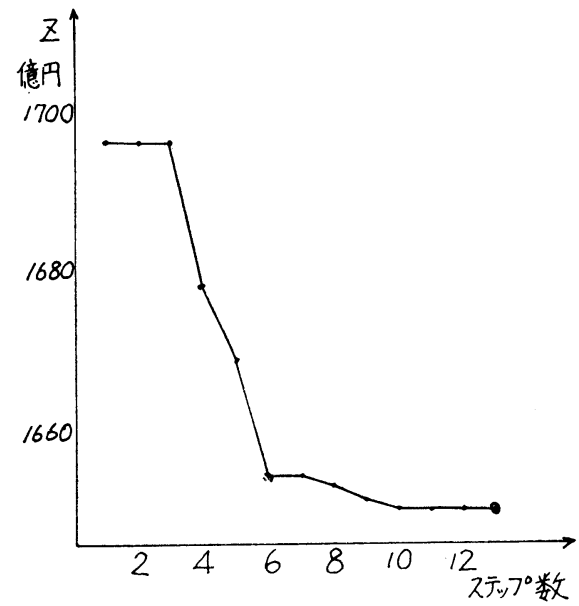

図 11 目的関数 $z$ の值の変化 (ケース I)

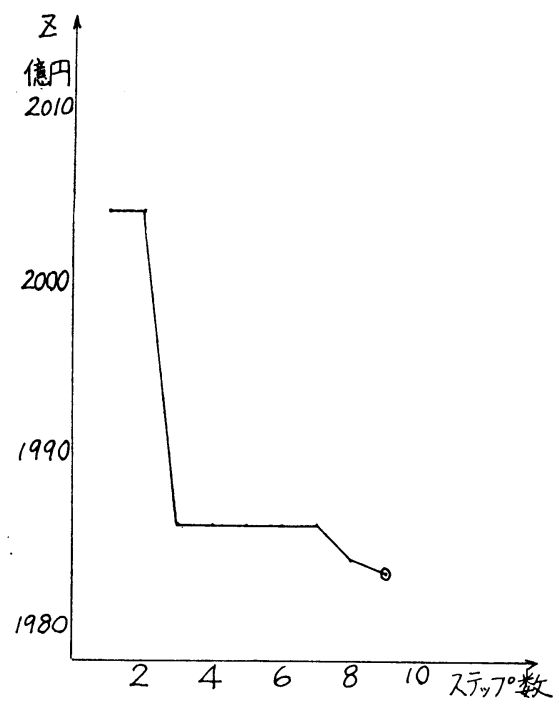

図-12 目的関数 $z$ の值の変化（ケース II）

き換えられていくことがわかる。その際に用いられる判 定基準の変化を各ステップごとに図一9および図一10に 示した。また $\lambda^{(k)}, \mu^{(l)}$ は各ステップにおける個々の実 行可能解 (代替案) に付すべき重みを表わしている。ま た，全体における実行可能解の改善の過程は，目的関数 $z$ の変化をみればわかるが，これをそれぞれケースI， II の場合について図示すれば，図一11 および図-12の ようになる。この図より明らかなように, 目的関数 $z の$ 変化が大きい段階は，ケース I の場合にはステップ 6 か らステップ 8 あたりまで，ケース II の場合にはステッ プ 2 から 3 までであり，以降はほとんど目的関数の值が 変化していない。これはダム群と導水路網の調整では, あらかじめダム群の調整が行なわれてから後にはじめて 導水路計画が策定されることが妥当であることを示して いる。これは, 導水路の建設費がダム群の建設費に比し
て 1 桁分だけ小さいといら事実に基づいている。この調 整状況は，まずダム群の建設計画案が決定してから導水 路網の計画案を策定するという従来の計画案策定過程と よく対応しており，このことは，ここでとりあげた計画 モデルの妥当性を保証するものと考えてもよいであろ ら。

b) と め

以上 2 つの場合について項目別に結果を考察したが, 以下ではこれらの結果から結論できることを要約するこ とにする。

本研究で取扱った兵庫県の利水計画のように, 近い将 来において特定の地域に急激な水需要が集中する反面, 他の地域においては水供給にゆとりがあると予測される 場合には，これらの地域を越えた水供給すなわち広域利 水計画が有効な手段となると考えられる。特に水配分と 関連給水施設の建設計画に限定して考える場合，建設費 用の観点からも合理的であることが示される。

次に，広域的なダム建設ならびに関連導水路網建設涻 画を策定する場合には，従来のようにダム建設計画が独 自に先行し，これに従属するような形で導水路網建設計 画が策定されることがよいかどうかを検討する必要があ る。すなわち，これは，広域利水方式の場合には，地域 を越えて導水するため，単にダムの建設のみならず，導 水路の建設も同時に考慮することが必要であることや, 導水路の建設費用が従来に比べて非常に高くなるため, 建設費の総和を問題にする以上，導水路の費用を無視す ることができなくなるからである。

広域利水計画のモデル化にあたっては，このような点 を考慮し，(1) ダム建設の位置選定と 規模を計画する機 能，(2) 建設されるダムと需要地とを結ぶ 導水路網の位 置・規模を計画する機能，(3) (1)，(2) の計画を合理的に 調整する機能の 3 種類が組み込まれる必要がある。上述 したように，(1),(2)の機能をモデルにより表わすと，(3 の調整機能は,このモデルにディコンポジションの原理 を適用することにより表現することができるので，その 調整過程に検討を加えることが可能となる。

ディコンポジションの原理を適用した兵庫県の広域利 水計画を検討した結果についてのみいえば，従来のよう にダム建設計画の策定を先行させても，決して不合理で はないことが示されている。すなわち，ダム群のダム少 イトと規模を決定した上で，導水路網の計画案を練ると いら従来の方式が計算結果からほぼ妥当であることが示 されている。しかしながら，現在に比して将来の導水路 網の建設費や需要量が急増した場合，さらにはより広域 的な利水計画を考えた場合には，この限りでないことも 理論的に明らかである。試みに需要量を大きくさせて感 度分析を実施してみると，ダム計画のみの最適解は全体 
の最適解を構成しないことが明らかとなっている。

c）モデルに関する検討

(1) 費用算定に関する検討：上記の実証例で述べたよ らに，現実のデータからは建設費用と規模の間にはほぼ 線形性が仮定できるものと判断したが，実際にはダムの 建設費用の算定はかなり複雑であるので，場合によって はこのような仮定が大きな誤差を生むことになる可能性 がある。特に，昨今におけるダムの建設費の $50 \%$ 以上 が土地収用費, 補修費で占められていること, さらに は，この費用が地域条件ならびにその時点の社会情勢に よって極端に相違してくることなど, 費用の算定にあた って対象ごとに具体的にほりさげたデ一タの収集が必要 であると考えられる。

また，建設費用と規模との間の関係は，厳密には非線 形で規模の経済性もみられるが，このモデルの対象とし ている計画のレベルとそこで必要とされる精度などを考 虑すれば，この仮定でも十分妥当であると考えられた。 さらに, 評価の尺度として建設費用の総和をとったが, これも必ずしも適切であるとは断言できないといらこと もある。したがって評価の尺度に関する研究を実施し, より適当な評価基準を導入していくことが今後に残され ている。

(2) 需要量の算定に関する検討 : 本モデルの実証計算 においては, 各河川の下流に従来の方法によって需要地 を設定した。すなわちこの需要量はあらかじめ各河川の 下流域に位置する需要地の需要量を各水系に割りふって 求めたものである。その際には, 各河川の流域に位置す る各需要地は，末端においてはもよりの河川に依存する と考えたものである。そのため末端の配水管の敷設はこ の方針にのっとって行なわれるとした。しかしながら各 需要地の需要量を各河川にどのように割りふるかによ。 て，下流に設定する需要量の算定値が異なり，ひいては 広域的な導水路の建設方法も変化するであろう。またこ のことは末端の配水管の敷設が現在どのような状態であ るのか, 将来においてどのように拡充していくのか等々 の問題と密接に関係している。したがって今後このモデ ルを用いて需要量を算定するためには，さらに検討を加 える必要があると考えられる。

\section{5. 結言}

以上のように本研究は, 広域利水に関する問題のらち から特に中心をなすと考えられる水配分問題をモデル化 するとともに，手段としてのダム群と，それと一対をな す導水路網との両者の建設計画に打ける調整過程の記述 を試みたものである。すでに述べたように，本モデルは いくつかの前提条件の下に成り立っているが,ここには
モデル構成における問題点と, モデル運用における問題 点が存在していると考える。以下では, 本研究の今後の 課題のとりまとめという観点から，これらの問題点を整 理し，簡単に述べることにする。

\section{（1）モデル構成における問題点}

本モデルは, 広域利水における水配分問題を対象とし ているのであるから，一般的な利水問題の中から広域利 水計画に関連する部分のみを取扱ったものである。この 場合, 技術の点でモデルにおいて直接に取上げられなか った項目が存在する。これらの項目は, 以下に述べるよ らな各項目に整理されよう。

2. (1)でも述べたように, 広域利水にも種々の段階の 計画が存在する。本モデルで取り上げたのは，広域的な 水配分問題を総合的な立場から検討するための計画情報 を提示することを目的としたものである。この点でモデ ルの記述範囲はおのずと限定され, 計画レベルと一致さ せるような形となっている。このため, 末端の給配水計 画をきめ細かく決定するための情報は, 他の側面からの 分析に委ねられる形となっている。

また, 水理・水文学, 河川工学上の技術的な側面から の考察は特に行なっていない。たとえば,

(1) ダム建設後の上流・下流部の河床の変動ならびに その対策

(2) 導水路の建設後の河川との分流点における河床の 変動・河道の変化とその対策

(3) ダムを河口堰として建設する場合の塩水の遡上と 塩水対策

(4) 流路の変更による地下水の変化や漁業などに与え る影響

などが考えられる。

また, 本広域利水計画を必要とする地域に関する種々 の社会科学的分析あるいは生態学的な分析という検討方 法についてはなんら言及していない。たとえば，地域に おける種々の活動の予測やその他の地域的要因を分析す ることにより，モデルのインプットデータと適用条件を 決めなければならないが，モデル適用前にこの点に関し ての十分な吟呼をしておくことが必要である。また，モ デルを適用して㬰証計算を行なった場合，得られた結果 を分析・検討するためには，地域における種々の活動に 与える影響や自然の変化などの社会科学的・生態学的観 点から考察を加えることが必要になってくると考えられ るが，この点についても本研究では取上げていない。

また, 実際問題としては, ダム群の計画の代替案なら びに導水路の計画の代替案は, 上記の種々の側面から検 討を加えることにより選び出されるべきものであり，単 に式 (1), 式 (2) を満たす代替案を, それぞれダムなら 
びに導水路の計画代替案とよぶのは必ずしも妥当ではな い。ここでは総合化の評価基準として両者の建設費の総 和に限定して分析を加えたものである。実際問題として は, 上に述べたいくつかの観点から関連する要因を評価 し, 実行可能性と優劣を総合的に比較検討することが肝 要であると考えられる。つまり, 計画の総合化では, 計 画にかかわる種々の評価要因に関する同時的かつ総合的 な検討が必要であるが，現在のところこれらに答えらる だけの計画技術が存在しておらず，これを補らためには 計画者の高度な総合判断の能力が必要となってくる。

このモデルでいら総合化のプロセスの定式化とは，建 設費用のみに注目した場合に限って, 費用といら側面か らの各代替案の優劣の比較を行ない, 効率のよい総合化 (調整過程) の記述を目指したものであるので，これら の分析結果は計画の総合化のための判断資料としての取 扱いが必要である。

\section{（2）モデル運用上の問題点}

これについては, 先に 4. (6)の c) で詳述したので, ここでは簡単に記しておくにとどめる。

まず，費用算定において施工条件を一定として考えた が，もしこの条件の検討も同時に行なえば，算定された 費用も異なり，その結果計算結果も異なることがありう ると考えられる。たとえば, 兵庫県の実証例における導 水路の建設に関しては, 地質構造からみたとき, 円山川 ・市川間の導水路の施工条件仕異なるため, その算定值 の大きさも逆転しうると考えられる。また実際の河川の 河道を導水路として用いる場合には, 建設費用は 0 とし て考えたが，筑堤・護岸工事その他の必要から必ずしも 0 とみなせない場合も考えられる。

これらの問題点は, 若干モデルの構成における除外項 目として列挙したものと重複しているが, なんらかの形 で費用に反映させることができるものもあり得ることを 示している。要するに, これらの問題点はあくまでデー タの精度に関するものであり, モデルの構造自体の問題 ではない。したがって今後のモデルの適用に当たって は, その場合に応じて, 要求される精度が満たされるよ らにデータの収集と検討をきめ細かく行ならことにより 解決しらると考えられる。
以上に述べてきたように，このモデルを実際のダムの 建設計画と導水路網の建設計画との総合化に用いる場合 は, 記述したさまざまな問題点について, 今後引続いて 検討していくことが必要であるが, 得られた成果は, こ れらの分析結果が, 水資源開発計画を策定していくらえ での有効な情報を提供しえた点にあると考えている。今 後, モデルの検討で述べた点をふまえ, モデルの改善な らびに他の角度からの広域利水問題の分析とモデル化を 行なっていきたいと考えている。

最後に，本研究を実施するにあたって有益なご助言を たまわった京都大学工学部土木工学教室吉川和広教授に 梁く感謝するとともに, 資料の収集に協力いただいた建 設省近畿地方建設局ならびに兵庫県の関係各位に謝意を 表します。

\section{参考文献}

1）建設省 : 近畿圈の 水資源実態調査, 建設省近畿地方建設 局, 昭和 45 年.

2）兵庫県: 兵庫県水資源 開発計画案概要, 兵庫県企画部, 昭和 45 年.

3）建設省 : 広域利水調査, 昭和 45 年.

4）建設省 : 大阪湾 紀伊水道地域大規模開発計画調査, 建設 省計画局, 昭和 46 年 1 月.

5）吉川和広・春名攻・岡田憲夫 : ダム群と配水施設の 配置 計画に関する一考察, 土木学会第 26 回年次学術講演会講 演集, 昭和 46 年.

6）吉川和広・春名攻・岡田憲夫 : 都市における 給配水施設 の拡張計画モデルについて, 土木学会第 27 回年次学術講 演会講演集, 昭和 47 年.

7）春名攻・岡田憲夫 : 兵庫県の広域利水計画に関する一考 察, 近畿都市学会, 昭和 47 年 6 月.

8）石橋多聞 : 飲み水の危機, 東京大学出版会, 昭和 47 年.

9) 科学技術庁: 将来の資源問題 (上), 科学技術庁, 昭和 46 年.

10）佐藤武夫：水の経済学, 岩波新書, 昭和 40 年.

11) M. Hufschmidt et al. : Design of Water Resources, Harvard Univ. Press.

12) A.V. Kneese \& S.C. Smith : Water Research, The Johnes Hopkins Press.

13) G.B. Dantzig : Linear Programming and Extensions, Princeton Univ. Press.

14) G. Hadley : Linear Programming, Addison-Wesley Publishing Company.

15) R.W. Llewellyn : Linear Programming, Holt, Rinehart and Winston.

(1972.7.18 - 受付) 